\title{
A new species of freshwater amphipod (Crustacea, Amphipoda, Hyalellidae) from state of Rio Grande do Sul, Southern Brazil
}

\author{
Morgana Taís Streck Marx ${ }^{l}$ \& Daniela da Silva Castiglioni ${ }^{2 *}$ [D \\ ${ }^{1}$ Universidade Federal de Santa Maria, Centro de Ciências Naturais e Exatas, Programa de Pós-Graduação \\ em Biodiversidade Animal, Av. Roraima, 1000, Camobi, 97105-900, Santa Maria, RS, Brasil \\ ${ }^{2}$ Universidade Federal de Santa Maria, Laboratório de Zoologia e Ecologia, Av. Independência, 3751, \\ 983000-000, Palmeira das Missões, RS, Brasil \\ *Corresponding author: Daniela da Silva Castiglioni, e-mail: danielacastiglioni@yahoo.com.br
}

STRECK-MARX, M. T., CASTIGLIONI, D. S. A new species of freshwater amphipod (Crustacea, Amphipoda, Hyalellidae) from state of Rio Grande do Sul, Southern Brazil. Biota Neotropica. 20(1): e20190802. http://dx.doi.org/10.1590/1676-0611-BN-2019-0802

\begin{abstract}
The current study describes a new species of Hyalella found in a natural pond at the municipality of Palmeira das Missões, located in the northwestern region of state of Rio Grande do Sul, southern Brazil. The new species differs from other species found in state of Rio Grande do Sul (Hyalella bonariensis, H. castroi, H. kaigang, H. imbya, H. georginae, H. gauchensis, H. montenegrinae and H. pampeana) in the type and number of setae on uropods, on telson and on the inner face of gnathopod 1. Besides, Hyalella palmeirensis is morphologically similar to H. curvispina, especially in the shape and number of setae of uropods. However, H. palmeirensis differs from H. curvispina in having only two simple setae on telson, the inner face of gnathopod 1 with five serrate setae and only the posterior distal margin with denticles in comb-scales, and especially by the tubular sternal gills, present on segments 3 to 7 . These new records increase from 11 to 12 the number of species known from state of Rio Grande do Sul.
\end{abstract}

Keywords: Freshwater crustaceans, Hyalella, Peracarida, taxonomy.

\section{Uma nova espécie de anfípodo dulcícola (Crustacea, Amphipoda, Hyalellidae) do estado do Rio Grande do Sul, sul do Brasil}

Resumo: O presente trabalho descreve uma nova espécie de Hyalella encontrada numa nascente no município de Palmeira das Missões, localizado na região noroeste do estado do Rio Grande do Sul, sul do Brasil. A nova espécie difere das outras espécies encontradas no estado do Rio Grande do Sul (Hyalella bonariensis, H. castroi, H. kaigang, H. imbya, H. georginae, H. gauchensis, H. montenegrinae and H. pampeana) especialmente com relação ao tipo e número de setas dos urópodos, télson e superfície ventral do gnatópodo 1 . Além disto, H. palmeirensis é similar a H. curvispina, especialmente na forma e número de setas dos urópodos. Entretanto, H. palmeirensis difere de H. curvispina por possuir somente duas setas simples no télson, cinco setas serradas na superfície ventral do gnatópodo 1 e dentículos (comb-scales) somente na margem posterior do gnatópodo 1 e brânquias esternais presentes do segmento 3 ao 7. Esse novo registro aumenta para 11 o número de espécies de Hyalella conhecidas para o estado do Rio Grande do Sul.

Palavras-chave: Crustáceo dulcícola, Hyalella, Peracarida, taxonomia. 


\section{Introduction}

Amphipoda is a successful group of peracaridan crustaceans known in several aquatic environments, including freshwaters where it exerts dominance of the benthic community of lakes (Ishikawa and Urabe 2002; Rodrigues 2016). The latest classification of the Order is shown by Lowry and Myers (2013), and these authors presented a new Suborder called Senticaudata, comprising almost all freshwater Amphipoda species and many marine species that previously belonged to the defunct Suborder Gammaridea.

The Family Hyalellidae is represented only by Hyalella Smith, 1874, which occurs throughout the Nearctic and Neotropical biogeographic regions, and it is endemic of the Americas (Baldinger 2004), presenting restrict distribution of species (Bousfield 1996). There are 74 limnic crustacean species of Hyalella (Marrón-Becerra et al. 2014; Colla and César 2015; Streck et al. 2017; Bastos-Pereira et al. 2018), however the highest diversity of species occurs in South America, where 56 species are currently described (Rodrigues et al. 2014, Colla and César 2015; Streck et al. 2017; Bastos-Pereira et al. 2018).

Brazil has the greatest number of Hyalella species described in the world, 27 in total (Bueno et al. 2013; Bueno et al. 2014; Cardoso et al. 2014; Rodrigues et al. 2014; Streck et al. 2017; Rodrigues et al. 2017, Bastos-Pereira et al. 2018). According to Bueno et al. (2014) and Streck et al. (2017) the state of Rio Grande do Sul (Southern Brazil) is the region with the highest species diversity in the country, counting 11 described species. With the finding of this specie the state of Rio Grande do Sul account now with 12 Hyalella species, the same number of species observed in all Southeast region of Brazil.

A new species of Hyalella is described from the municipality of Palmeira das Missões, northwest region of state of Rio Grande do Sul, southern Brazil.

\section{Material and Methods}

The municipality of Palmeira das Missões is located at the northwest region of state of Rio Grande do Sul, Southern Brazil. The specimens were collected in August/2012 and the sampling was made with the aid a hand net, with authorizations of the Instituto Chico Mendes de Conservação da Biodiversidade (MMA; ICMBio; SISBIO no 32726-1).

Head length of the animals was measured through an optic microscope with a millimetric scale. Adult males and females were preserved in ethanol 70\%, colored with Rose Bengal and dissected. A total of 15 individuals ( 10 males and 5 females) were dissected and the appendices were mounted on permanent slides. Illustrations were made using photos and the CorelDraw program.

The description was made based on main morphological characteristics such as the gnathopods, uropods and telson, according to González et al. (2003a, b), González et al. (2006), Cardoso et al. (2011), and Bastos-Pereira and Bueno (2012). The terminology used for the setae of the appendices follows Zimmer et al. (2009).

The description was based on male paratype and female allotype. The type material is deposited in the Museu Nacional do Rio de Janeiro (MNRJ).

\section{Results}

Taxonomy

Order Amphipoda Latreille, 1816

Suborder Senticaudata Lowry \& Myers, 2013

Family Hyalellidae Bulycheva, 1957

Genus Hyalella S. I. Smith, 1874

\section{Hyalella palmeirensis n. sp. Streck-Marx \& Castiglioni}

Type material: Holotype male, total body length $=5.32 \mathrm{~mm}$, head length $=0.50 \mathrm{~mm}$ (MNRJ 26584); Allotype female (MNRJ 26585). Brazil, state of Rio Grande do Sul, Palmeira das Missões municipality (27 56.949' S - 53 ${ }^{\circ} 19.613^{\prime}$ W), August, 24, 2012, Castiglioni, D.S. coll.

Paratypes: Mean total body length of male paratypes: $5.50 \pm 0.78$ mm and female paratypes: $5.00 \pm 0.50$ (20 males and 20 females) (MNRJ 26586), same date as holotype, Castiglioni, D.S. coll.

Type-locality. Brazil, state of Rio Grande do Sul (2756.949'S $53^{\circ} 19.613^{\prime}$ W), state of Rio Grande do Sul, Palmeira das Missões municipality, natural pond, 560 m, August, 24, 2012, Castiglioni, D.S. coll.

Diagnosis. Body surface smooth. Eyes round, pigmented. Antenna 1 shorter than antenna 2, flagellum with 11/12 articles and longer than peduncle, two aesthetascs occurring distally on flagellum after article 5. Antenna 2 flagellum with 10/11 articles and longer than peduncle. Maxilla 1 palp uniarticulate, short, longer than wide, inner plate shorter and slender than outer plate, with two long apical papposerrate setae, and some setules on the inner margin; outer plate with nine serrate setae. Maxilla 2 inner plate with only one long and strong papposerrate seta and several simple and serrate setae. Gnathopod 1 with inner face with five serrate setae, posterior distal margin with denticles in comb-scales, one cuspidate seta and some simple setae. Gnathopod 2 propodus longer than wide and with posterior margin of small lobe covered by denticles in comb-scales; palm smooth and sub-equal to posterior margin of propodus, slope oblique, palm margin convex; dactylus claw-like, short, not reaching the lobe of propodus; carpus wider than long, posterior lobe elongated, with pectinate border and one row of serrate setae, without polygonal pattern or comb-scales. Pleopods rami with long plumose setae. Uropod 1 inner ramus with a long-curved seta followed by a row of five small cuspidate setae with an accessory seta. Uropod 2 inner ramus apex with five cuspidate setae with an accessory seta and two cuspidate simple setae. Uropod 3 peduncle with three cuspidate setae with accessory setae apically, small cuspidate setae and simple setae distributed along the peduncle and ramus. Telson (male) longer than wide, with two apical simple setae, and three plumose setae close to each simple seta. Coxal gills sac-like present on segments 2 to 6 and sternal gills tubular, presents on segments 3 to 7 .

Description of male. (Fig. 1a) Mean body length: $5.50 \pm 0.78$, mean head length: $0.52 \pm 0.07 \mathrm{~mm}(\mathrm{n}=20)$. Head longer than the first thoracic segment, rostrum absent. Eyes round, pigmented.

Antenna 1 (Fig. 1b) shorter than antenna 2, peduncle not surpassing head length, flagellum with $11 / 12$ articles, longer than peduncle; aesthetascs occurring distally on flagellum after article 5 .

Antenna 2 (Fig. 1c) peduncle less than half body length, with very few setae; flagellum with 10/11 articles and longer than peduncle. 
A new species of freshwater amphipod

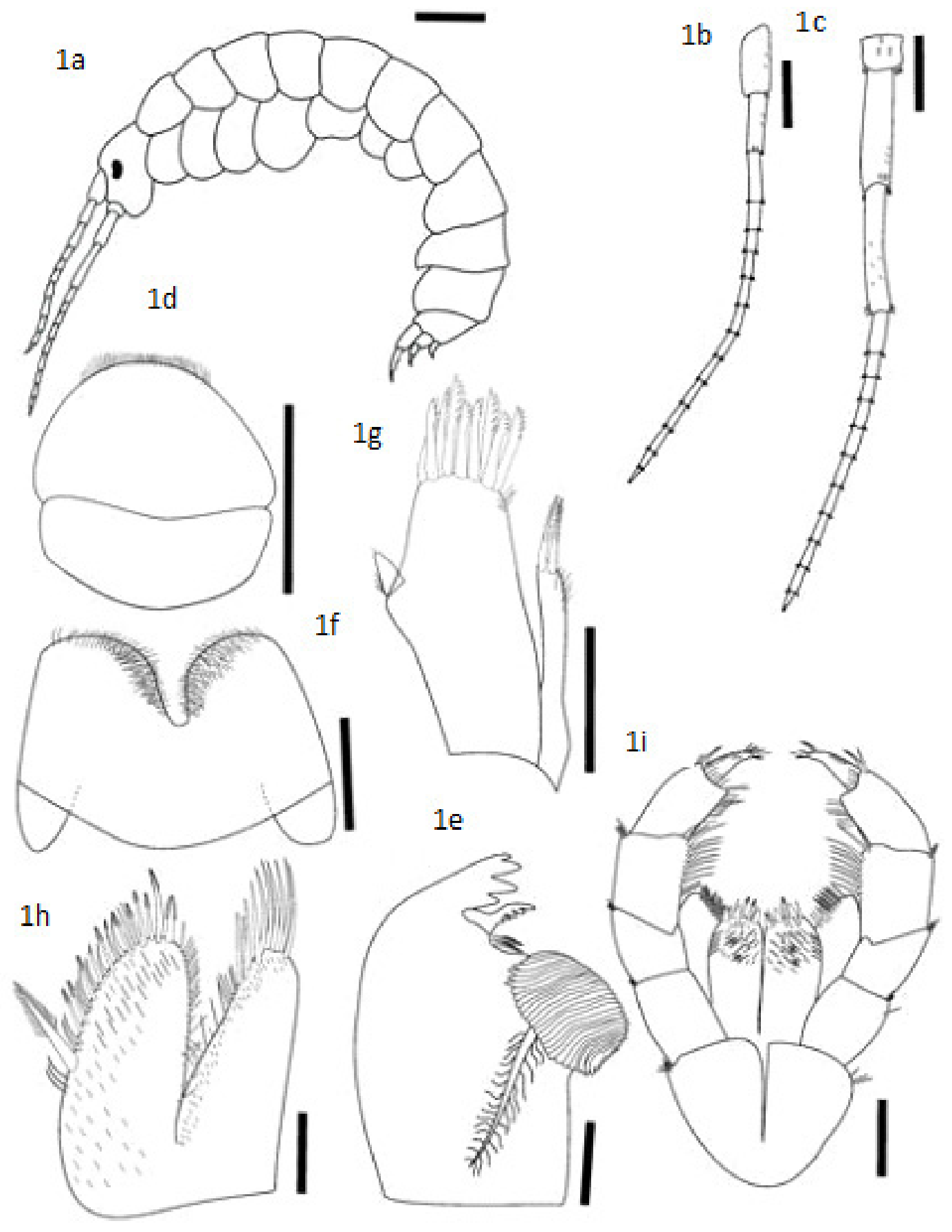

Figure 1. Hyalella palmeirensis n. sp. Paratype male (MNRJ 26586): (a) Habitus from holotype (MNRJ 26584), body length: 5.32 mm; (b) Antenna 1; (c) Antenna 2; (d) Upper lip; (e) Left mandible; (f) Lower lip; (g) Maxilla 1; (h) Maxilla 2; (i) Maxilliped; Scales: (1a-1c) represents $0.5 \mathrm{~mm}$; (1d-1g) $0.2 \mathrm{~mm}$; (1h) $0.05 \mathrm{~mm}$; (1i) $0.2 \mathrm{~mm}$. 
Upper lip (Fig. 1d) margin rounded, distal border covered by several setules on dorsal and ventral faces.

Basic amphipodan mandible (Fig. 1e) (in sensu of Watling 1993), without palp; incisor toothed; left lacinia mobilis with five teeth and with three pappose setae; molar process large, cylindrical and with large accessory seta.

Lower lip (Fig. 1f) outer lobes rounded without notches or excavations, with several setules on dorsal and ventral faces.

Maxilla 1 (Fig. 1g) palp uniarticulate, short, longer than wide, reaching less than half length the distance between the base of the palp and tip of setae on outer plate; inner plate uniarticulate, shorter and slender than outer plate, with two long apical pappose setae. Outer plate uniarticulate, with 9 serrate setae.

Maxilla 2 (Fig. 1h) inner plate with one long and strong papposerrate seta, several simple and serrate setae; outer plate with one row of simple setae.

Maxilliped (Fig. 1i) inner plates apically truncated, with three connate setae and pappose and simple setae apically and medially; outer plates larger than inner plates, apically truncated, apical, medial, and facial setae simple. Palp of four articles with simple setae and few pappose setae; dactylus unguiform, shorter than propodus, with simple setae and comb-scales.

Gnathopod 1 (Fig. 2a) subchelate; dactylus claw-like, with denticles in comb-scales and one plumose seta dorsally; propodus longer than wide, width about $3 / 4$ of maximum length (rectangular), hammer-shaped, palm slope slightly oblique and margin sinuose with several simple setae, posterior distal margins with comb scales, one cuspidate setae and some simple setae, anterodistal margin without comb scales, but with six or seven simple setae, propodus inner face (ventral) with five serrate setae; carpus longer than wide, slightly longer than propodus, with strong lateral distal lobe produced and forming a scoop-like structure, posterior lobe of carpus with one row of serrate setae and without comb-scales; basis, ischium and merus with simple setae dorsally, without comb-scales posterodistally; coxal plates longer than wide.

Gnathopod 2 (Fig. 2b) subchelate; dactylus claw-like, short, not reaching the lobe of propodus, with one plumose seta dorsally, without comb-scales; propodus longer than wide (ovate), propodus length 1.5 times the maximum width, posterior margin of lobe almost straight and covered with denticles in comb-scales; palm margin convex, with several cuspidate setae with accessory setae and simple setae, posterior distal corner with few simple setae; carpus wider than long, posterior lobe elongated, with pectinate border with one row of serrate setae and without polygonal pattern or comb-scales; ischium and merus with few simple setae on posterodistal margin; basis, ischium and merus without comb-scales on posterior margin; coxal plate wider than long.

Peraeopods 3 to 7 (Fig. 3a to 3e) dactylus, propodus, carpus, merus, ischium and basis with simple and cuspidate setae with accessory seta. All coxal plates with simple setae on the border.

Pleopods (Fig. 4a) not modified, peduncle slender, smaller than flagellum rami, and two distal coupling spines; both rami with long plumose setae.

Uropod 1 (Fig. 4b) peduncle slightly (1.2 times) longer than rami, with four cuspidate setae with an accessory seta dorsally; inner ramus longer than outer ramus; inner ramus with two dorsal cuspidate setae with an accessory seta, male with a curved seta followed by a row of five small cuspidate setae with an accessory seta, two cuspidate setae apically; outer ramus with three dorsal cuspidate setae with an accessory seta and four cuspidate setae apically (two of them with an accessory seta).

Uropod 2 (Fig. 4c) shorter than uropod 1; peduncle rectangular with similar size as rami, with four cuspidate setae with an accessory seta dorsally; inner ramus slightly longer than outer ramus, with two dorsal cuspidate setae with an accessory seta and seven cuspidate setae apically (five with an accessory seta); outer ramus with two dorsal cuspidate setae with an accessory seta and apex with four cuspidate setae (two with an accessory seta).

Uropod 3 (Fig. 4d) peduncle slightly longer than wide, wider than ramus, with three cuspidate setae with an accessory seta and one simple seta apically, two simple setae distributed along the peduncle; ramus with five simple setae and a short, strong cuspidate setae.

Telson (Fig. 4e) is longer than wide, with two long simple setae and three plumose setae close to each simple seta.

Coxal gills sac-like, present on segments 2 to 6 . Sternal gills tubular on segments 3 to 7 .

Female. Mean total body length: $5.00 \pm 0.50$, mean head length: $0.47 \pm 0.05(n=20)$. Antenna 1 similar shape to male but with flagellum of 7-8 articles. Antenna 2 similar in shape to male, flagellum of 8-9 articles.

Gnathopod 1 (Fig. 5a) similar to male gnathopod 1, similar size to gnathopod 2; dactylus with comb-scales and plumose seta; propodus longer than wide, hammer-shaped, inner face with five serrate setae and two long simple setae and several short simple setae, anterior distal margin without comb-scales but two simple setae and distally with six or seven short simple setae, posterior distal margin with comb-scales and two simple setae and posterior distal corner with one strong cuspidate seta; carpus longer than wide, with lateral distal lobe produced and forming a scoop-like structure, posterior lobe margin with polygonal pattern and with serrate setae and without comb-scales; base, merus and ischium without comb-scales on posterior margin.

Gnathopod 2 (Fig. 5b) similar in size to gnathopod 1, but the propodus of gnathopod 2 is slightly longer than gnathopod 1; different to male gnathopod 2 in shape and smaller; dactylus with comb-scales and one plumose seta; propodus rectangular, longer than wide, inner face with four serrate setae and two long simple setae and several short simple setae, palm transverse, posterior distal corner with one strong cuspidate seta, posterior distal margins with comb-scales and two simple setae and anterior margin without comb-scales; base, merus and ischium without comb-scales on posterior margin. Telson similar in shape to male, with two long simple setae and three plumose setae close to each simple seta.

Habitat. Freshwater, epigean. Hyalella palmeirensis was found in a natural pond of shallow depth (around $40 \mathrm{~cm}$ ) (Fig. 6a and 6b). The pond contains a large amount of macrophytes of the genus Egeria which were used as shelter for the specimens of H. palmeirensis.

Etymology. The specific name, palmeirensis, refers to native residents of Palmeira das Missões municipality, southern Brazil.

Remarks. We noted using the taxonomic key of Rodrigues et al. (2014) that $H$. palmeirensis differs from the other species of the genus in Brazil. Hyalella palmeirensis resembles $H$. bonariensis, $H$. montenegrinae, H. curvispina, H. castroi, H. imbya, H. pseudoazteca, 
A new species of freshwater amphipod

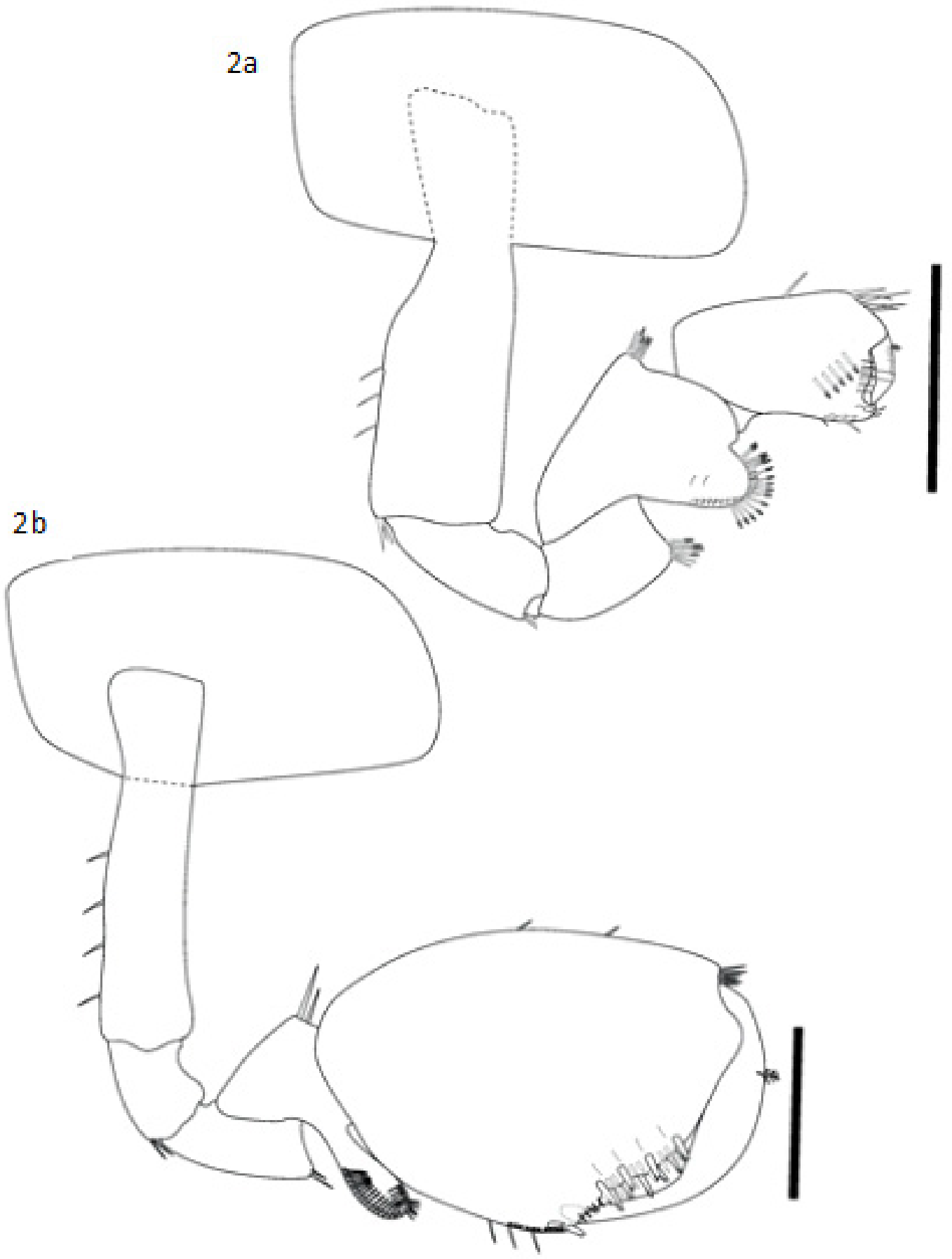

Figure 2. Hyalella palmeirensis n. sp. Paratype male (MNRJ 26586); (a) Gnathopod 1; (b) Gnathopod 2; Scales: (2a-2b) represents $0.5 \mathrm{~mm}$. 
Streck-Marx, M. T. \& Castiglioni, D.S.

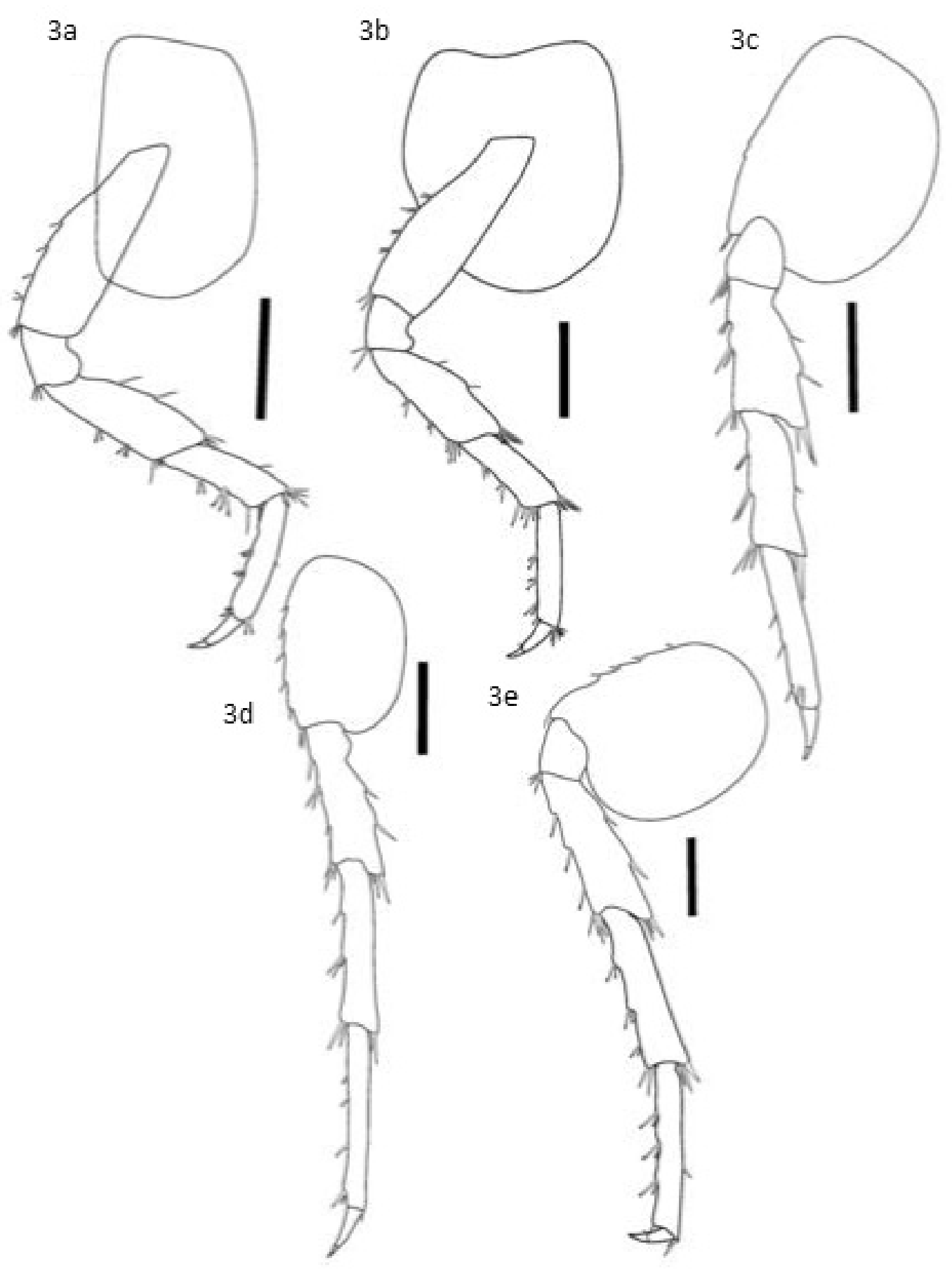

Figure 3. Hyalella palmeirensis n. sp. Paratype male (MNRJ 26586); (a) Peraeopod 3; (b) Peraeopod 4; (c) Peraeopod 5; (d) Peraeopod 6; (e) Peraeopod 7; Scales: (3a-3e) represents $0.5 \mathrm{~mm}$. 
A new species of freshwater amphipod

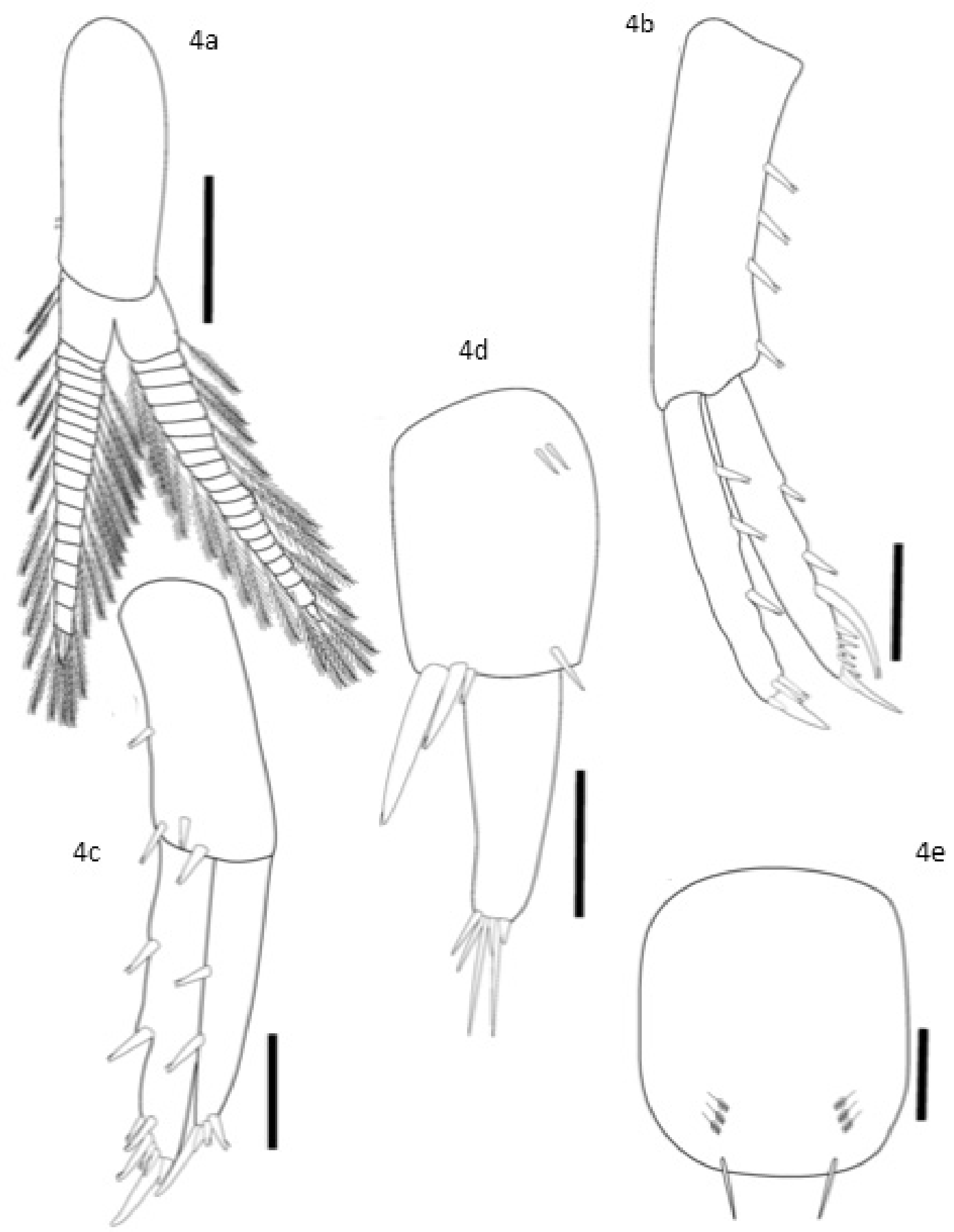

Figure 4. Hyalella palmeirensis n. sp. Paratype male (MNRJ 26586); (a) Pleopod; (b) Uropod 1; (c) Uropod 2; (d) Uropod 3; (e) Telson; Scales: (4a) represents $0.5 \mathrm{~mm}$; (4b-4d) $0.2 \mathrm{~mm}$; (4e) $0.05 \mathrm{~mm}$. 

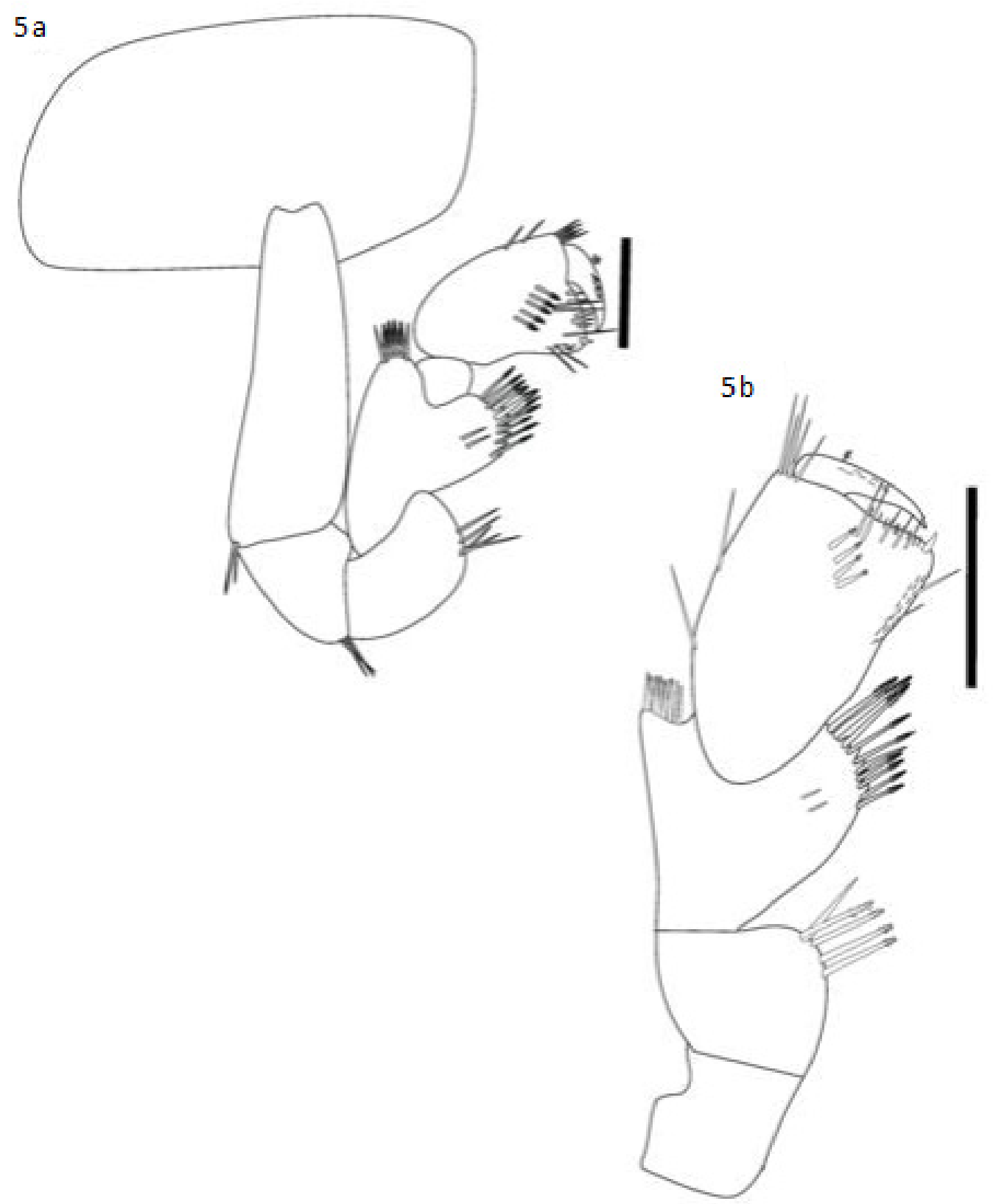

Figure 5. Hyalella palmeirensis n. sp. Allotype female (MNRJ 26585); (a) Gnathopod 1; (b) Gnathopod (2) Scales: (5a-5b) represents $0.2 \mathrm{~mm}$.

H. kaingang, H. pampeana, H. pleoacuta, H. carstica, H. xakriaba, $H$. georginae and H. gauchensis, by having a curved seta on the inner ramus of uropod 1 of the males.

Besides, $H$. palmeirensis resembles $H$. montenegrinae, $H$. carstica and H. montana Rodrigues et al., 2017 in having sternal gills on segments 3-7. The new species resembles $H$. curvispina, $H$. castroi, H. pseudoazteca, H. kaingang and H. pleoacuta in having the dactylus of gnathopod 2 shorter than the propodus palm. Differs from $H$. bonariensis, $H$. castroi, H. kaigang H. imbya, H. georginae, $H$. gauchensis, $H$. montenegrinae and $H$. pampeana in the type and number of setae on uropods, telson and inner face of gnathopod 1. Hyalella palmeirensis is similar to H. curvispina, especially in the shape and number of setae of uropods. However, H. palmeirensis differs of H. curvispina in having only two simple setae on telson, inner face of gnathopod 1 with five serrate setae and only the posterior distal margin with denticles in comb-scales, and especially by tubular sternal gills present on segments 3 to 7 .

The new species Hyalella palmeirensis resembles $H$. misionensis, from the Province of Misiones in Argentina, in the telson (male) with two long apical simple setae. However, it differs in the curved seta on the inner ramus of uropod 1, inner face of propodus of gnathopod 1 and sternal gills. The area where $H$. misionensis was found is geographically close to Brazil. Comparisons between morphological characters of Hyalella species of Rio Grande do Sul are presented in Table 1. 

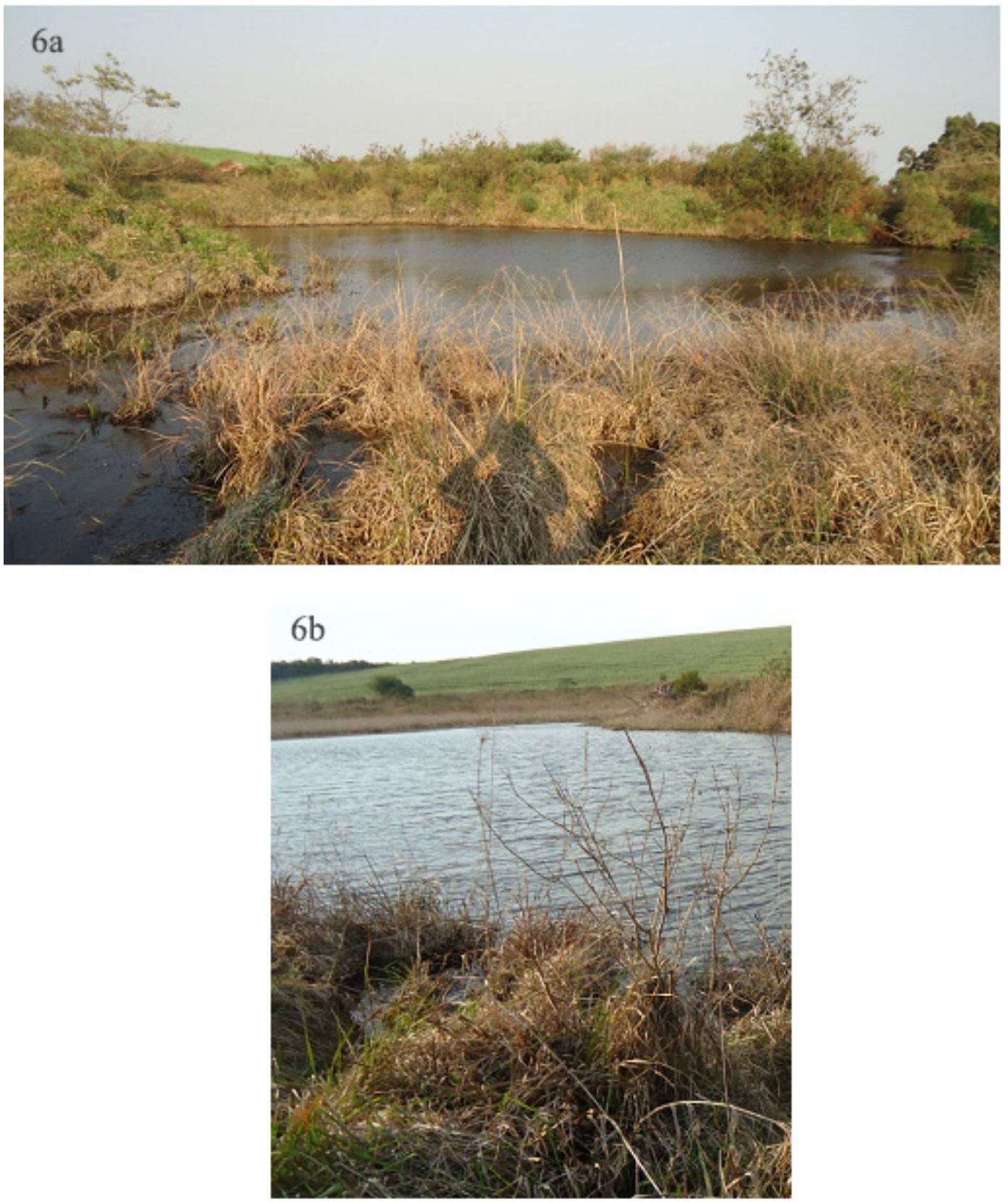

Figure 6. Type-locality of Hyalella palmeirensis n. sp. Streck-Marx \& Castiglioni; (a) Showing the natural pond of shallow depth (around $40 \mathrm{~cm}$ ). Note the large amount of macrophytes of the genus Egeria, which are used as shelter for the specimens of the new species; (b) Showing the natural pond of shallow and surrounding cultivation of any type of crops, as soy and rice which could be considered a threat to this species as the pesticides used in these cultures can be harmful to the amphipods.

\section{Discussion}

The new species described here, improves the diversity of Hyalella in the Southern region of Brazil, increasing the number of species found in the region, to 14, whereas 12 of them are observed in the state of Rio Grande do Sul, the same number of all southeastern region of Brazil (Bueno et al. 2014; Cardoso et al. 2014; Rodrigues et al. 2014).

In addition to morphological differences, other evidence that $H$. palmeirensis is a distinct species from others of the genus comes from a matrix of pairwise nucleotide sequence divergences using concatenated genes $16 \mathrm{~S}$ ( $\sim 650 \mathrm{bps}), 12 \mathrm{~S}$ ( $\sim 550 \mathrm{bps})$ and H3 ( 375bps) (Rodrigues 2016). This analysis showed that H. palmeirensis (called Hyalella sp. 20 by Rodrigues 2016) diverge at least $15.3 \%$ to $25.4 \%$ from $H$. curvispina, (the closest species), and 16.2\% from H. gauchensis (called Hyalella sp. 18 by Rodrigues 2016) and $17.6 \%$ from $H$. georginae (called Hyalella sp. 19 by Rodrigues 2016) (Rodrigues 2016). It should be noted that $H$. gauchensis and $H$. georginae are two species that occur in nearby areas where H. palmeirensis was sampled (Streck et al. 2017). Moreover, Rodrigues (2016) estimated the phylogeny of Hyalella reconstructed by Bayesian analysis and according to it, $H$. palmeirensis is statistically 
Streck-Marx, M. T. \& Castiglioni, D.S.

Table 1. Main morphological differences between Hyalella palmeirensis n. sp. Streck-Marx \& Castiglioni and 11 Hyalella species from nearby areas in the state of Rio Grande do Sul, Southern, Brazil.

\begin{tabular}{|c|c|c|c|c|c|c|c|c|c|}
\hline Species & $\begin{array}{l}\text { Body } \\
\text { surface }\end{array}$ & $\begin{array}{c}\text { Inner } \\
\text { margin of } \\
\text { maxila } 2\end{array}$ & $\begin{array}{c}\text { Articles of } \\
\text { flagellum } \\
\text { of antenna } \\
1\end{array}$ & $\begin{array}{c}\text { Articles of } \\
\text { flagellum } \\
\text { of antenna } \\
2\end{array}$ & $\begin{array}{l}\text { Inner face of } \\
\text { propodus of } \\
\text { gnathopod } 1\end{array}$ & $\begin{array}{c}\text { Setae on } \\
\text { peduncle } \\
\text { of uropod } \\
3\end{array}$ & Telson & $\begin{array}{l}\text { Sternal } \\
\text { gills }\end{array}$ & Tipe locality \\
\hline H. bonariensis & Smooth & $\begin{array}{l}\text { Two pappose } \\
\text { setae }\end{array}$ & $9-12$ & $12-15$ & 5 setae & 6 setae & $\begin{array}{l}\text { Quadrangular, } \\
\text { with } 2-3 \\
\text { cuspidate setae } \\
\text { apically }\end{array}$ & $2-7$ & $\begin{array}{l}\text { Province of } \\
\text { Buenos Aires, } \\
\text { Salto, Argentina }\end{array}$ \\
\hline H. castroi & Smooth & $\begin{array}{l}\text { One pappose } \\
\text { setae }\end{array}$ & $10-17$ & $14-18$ & $\begin{array}{l}\text { More than } 10 \\
\text { serrate setae }\end{array}$ & 7 setae & $\begin{array}{l}\text { Wider than long, } \\
\text { with } 8 \text { setae }\end{array}$ & $2-7$ & $\begin{array}{l}\text { Vale of trout, } \\
\text { Rio Grande do } \\
\text { Sul, Brazil }\end{array}$ \\
\hline H. curvispina & Smooth & $\begin{array}{l}\text { Two plumose } \\
\text { setae }\end{array}$ & 11 & 13 & $5-7$ setae & 3 setae & $\begin{array}{l}\text { Wider than long, } \\
\text { with } 3 \text { simple } \\
\text { spines }\end{array}$ & $2-7$ & $\begin{array}{l}\text { Lake Tramandai, } \\
\text { Rio Grande do } \\
\text { Sul, Brazil }\end{array}$ \\
\hline H. georginae & Smooth & $\begin{array}{l}\text { Two robust } \\
\text { papposerrate } \\
\text { apical setae }\end{array}$ & 15 & 16 & $\begin{array}{l}9 \text { serrate } \\
\text { setae }\end{array}$ & 9 setae & $\begin{array}{l}\text { Wider than } \\
\text { long, with } 7 \\
\text { apical cuspidate } \\
\text { setae with an } \\
\text { accessory seta, } \\
\text { and } 4 \text { plumose } \\
\text { setae laterally }\end{array}$ & $2-7$ & $\begin{array}{l}\text { Palmeira das } \\
\text { Missões, Rio } \\
\text { Grande do Sul, } \\
\text { Brazil }\end{array}$ \\
\hline H. gauchensis & Smooth & $\begin{array}{c}\text { Two } \\
\text { papposerrate } \\
\text { apical setae }\end{array}$ & 11 & 15 & $\begin{array}{l}\text { 9-20 serrate } \\
\text { setae }\end{array}$ & 6 setae & $\begin{array}{l}\text { Wider than long, } \\
\text { with } 6 \text { apical } \\
\text { cuspidate setae, } \\
\text { and } 6 \text { plumose } \\
\text { setae laterally }\end{array}$ & $2-7$ & $\begin{array}{l}\text { Palmeira das } \\
\text { Missões, Rio } \\
\text { Grande do Sul, } \\
\text { Brazil }\end{array}$ \\
\hline H. imbya & Smooth & $\begin{array}{c}\text { Two } \\
\text { papposerrate } \\
\text { setae }\end{array}$ & $18-23$ & $14-16$ & $\begin{array}{l}7 \text { serrate } \\
\text { setae }\end{array}$ & 1 seta & $\begin{array}{l}\text { Two long simple } \\
\text { apical setae }\end{array}$ & $3-7$ & $\begin{array}{l}\text { Roque Gonzales, } \\
\text { Rio Grande do } \\
\text { Sul, Brazil }\end{array}$ \\
\hline H. kaigang & $\begin{array}{l}\text { With dorsal } \\
\text { flanges on } \\
\text { pleonites } 1-2\end{array}$ & $\begin{array}{c}\text { Two } \\
\text { papposerrate } \\
\text { setae }\end{array}$ & $17-18$ & $18-24$ & $\begin{array}{c}2 \text { rows of } \\
\text { serrate setae }\end{array}$ & 6 setae & $\begin{array}{l}\text { Wider than } \\
\text { long, with 6-7 } \\
\text { cuspidate seta } \\
\text { with acessory } \\
\text { setae }\end{array}$ & $2-7$ & $\begin{array}{l}\text { Garapiá stream, } \\
\text { municipality of } \\
\text { São Francisco } \\
\text { de Paula, Rio } \\
\text { Grande do Sul, } \\
\text { Brazil }\end{array}$ \\
\hline H. montenegrinae & Smooth & $\begin{array}{l}\text { Two plumose } \\
\text { setae }\end{array}$ & $14-16$ & $14-19$ & $\begin{array}{l}\text { 9-10 } \\
\text { plumose } \\
\text { setae }\end{array}$ & $\begin{array}{l}4 \text { or } 5 \\
\text { setae }\end{array}$ & $\begin{array}{l}\text { Wider than long, } \\
7 \text { to } 9 \text { setae }\end{array}$ & $3-7$ & $\begin{array}{l}\text { São José dos } \\
\text { Ausentes, Rio } \\
\text { Grande do Sul, } \\
\text { Brazil }\end{array}$ \\
\hline H. pampeana & Smooth & $\begin{array}{c}\text { Two } \\
\text { bipectinada } \\
\text { setae }\end{array}$ & $11-12$ & Up to 18 & $5-6$ setae & $\begin{array}{l}5 \text { to } 7 \\
\text { setae }\end{array}$ & $\begin{array}{l}\text { As wide as long, } \\
\text { apically rounded, } \\
\text { with } 2-5 \text { spines }\end{array}$ & $2-7$ & $\begin{array}{l}\text { Province of } \\
\text { Buenos Aires, } \\
\text { Argentina }\end{array}$ \\
\hline H. pleoacuta & $\begin{array}{l}\text { With dorsal } \\
\text { flanges } \\
\text { on some } \\
\text { segments }\end{array}$ & $\begin{array}{l}\text { Two pappose } \\
\text { setae }\end{array}$ & 14 & 15 & $\begin{array}{l}9 \text { serrate } \\
\text { setae }\end{array}$ & 4 setae & $\begin{array}{l}\text { As long as wide, } \\
\text { with } 2 \text { simple } \\
\text { setae }\end{array}$ & $2-7$ & $\begin{array}{l}\text { Vale of Trout, } \\
\text { Rio Grande do } \\
\text { Sul, Brazil }\end{array}$ \\
\hline H. pseoudoazteca & $\begin{array}{l}\text { With dorsal } \\
\text { flanges } \\
\text { on some } \\
\text { segments }\end{array}$ & $\begin{array}{l}\text { One pappose } \\
\text { seta }\end{array}$ & 10 & $8-9$ & $\begin{array}{l}\text { 1-3 pappose } \\
\text { setae }\end{array}$ & 1 seta & $\begin{array}{l}\text { Wide as long, } 2 \\
\text { closely spaced, } \\
\text { long simple setae }\end{array}$ & $3-7$ & $\begin{array}{l}\text { Taim Ecological } \\
\text { Reserve, Rio } \\
\text { Grande do Sul, } \\
\text { Brazil }\end{array}$ \\
\hline H. palmeirensis & Smooth & $\begin{array}{l}\text { One pappose } \\
\text { setae }\end{array}$ & $11-12$ & $10-11$ & $\begin{array}{l}5 \text { serrate } \\
\text { setae }\end{array}$ & 3 setae & $\begin{array}{l}\text { Longer than } \\
\text { wide, with } 2 \text { long } \\
\text { simple setae and } \\
6 \text { plumose setae } \\
\text { laterally }\end{array}$ & $3-7$ & $\begin{array}{l}\text { Palmeira das } \\
\text { Missões, Rio } \\
\text { Grande do Sul, } \\
\text { Brazil }\end{array}$ \\
\hline
\end{tabular}


well supported in a different clade from $H$. curvispina, $H$ gauchensis and $H$. georginae, forming distinct groups which have divergence at 28.55 million of years ago.

The species Hyalella palmeirensis lives in association with macrophytes in a natural pond of shallow depth. The pond contains a large amount of macrophytes of the genus Egeria, which are used as shelter by H. palmeirensis. However, H. palmeirensis occurs in a natural pond surrounded by the cultivation of many types of crops, which could be considered a threat to this species as the pesticides used during cultivation can be harmful to the amphipods. Agricultural expansion, especially rice and soybean, is one of the main factors that affect and hinders conservation, because this activity not only remove the original vegetation for cultivation but also often bring out chemicals for soil remediation, pest control or fertilization, and cause fragmentation and deterioration of these ecosystems (Maltchik and Rolon 2010; Rodrigues et al. 2012).

\section{Acknowledgments}

We thank Coordenação de Aperfeiçoamento de Pessoal de Nível Superior (CAPES) and Conselho Nacional de Desenvolvimento Científico e Tecnológico (CNPq) for financial support (PROACAD CNPq n $\left.{ }^{\circ} 405061 / 2015-3\right)$. We also thank Prof. Dr. Alessandra Angélica de Pádua Bueno for contributions to the manuscript, especially by species identification. To Vanessa da Silva Castro and Francieli Ubessi for aid in collections.

\section{Authors Contributions}

Morgana Taís Streck Marx: contribution to data collection, manuscript preparation, data analysis and interpretation.

Daniela da Silva Castiglioni: contribution to data collection and concept and design of the study.

\section{Conflicts of interest}

The authors declare that they have no conflict of interest related to the publication of this manuscript.

\section{Ethics}

The sampling was made with authorizations of the Instituto Chico Mendes de Conservação da Biodiversidade (MMA; ICMBio; SISBIO $n^{\text {o } 32726-1) . ~}$

\section{Data availability}

The type material is deposited in the Museu Nacional do Rio de Janeiro (MNRJ).

\section{References}

BALDINGER, A.J. 2004. A new species of Hyalella (Crustacea, Amphipoda, Hyalellidae) from Ash Springs, Lincoln Country, USA, with a key to the species of the genus in North America and the Caribbean region. Journal of Natural History, 38: 1087-1096.

BASTOS-PEREIRA, R. \& BUENO, A.A.P. 2012. New species and new report of Hyalella S. I. Smith, 1874 (Crustacea: Amphipoda: Dogielinotidae) from Minas Gerais state, Southeastern Brazil. Zootaxa, 3350: 58-68.

BASTOS-PEREIRA, R., OLIVEIRA, M.P.A. \& FERREIRA, R.L. 2018. Anophtalmic and epigean? Description of an intriguing new species of Hyalella (Amphipoda, Hyalellidae) from Brazil. Zootaxa, 4407(2): 254-266. http://doi.org/10.11646/zootaxa.4407.2.6

BOUSFIELD, E.L. 1996. A contribution to the reclassification of Neotropical freshwater hyalellid amphipods (Crustacea: Gammaridea, Talitroidea). Bolletino del Museo Civico di Storia Naturale de Verona, 20: 175-224.

BUENO, A.A.P., ARAUJO, P.B., CARDoso, G.M., GOMES, K.M. \& BOND-BUCKUP, G. 2013. Two new species of Hyalella (Amphipoda, Dogielinotidae) from Brazil. Crustaceana, 86 (7-8): 802-819. http://dx.doi. org/10.1163/15685403-00003205

BUENO, A. A. P., RODRIGUES, S.G. \& ARAUJO, P.B. 2014. O estado da arte do gênero Hyalella Smith, 1874 (Crustacea, Amphipoda, Senticaudata, Hyalellidae) no Brasil. In: CARmino HayASHI. (Org.). Tópicos de Atualização em Ciências Aquáticas. 1ed. Uberaba: UFTM, 1: 57-88.

CARDoso, G.M., BUENO, A.A.P. \& FERREIRA, R.L. 2011. A new troglobiotic species of Hyalella (Crustacea, Amphipoda, Dogielinotidae) from Southeastern Brazil. Nauplius, 19(1): 17-26.

CARdoso, G.M., ARAUJO, P.B.; BUENO, A.A.P. \& FERREIRA, R.L. 2014. Two new subterranean species of Hyalella Smith, 1874 (Crustacea: Amphipoda: Hyalellidae) from Brazil. Zootaxa, 3814: 253-348. http://dx.doi.org/10.11646/zootaxa.3814.3.3

COLLA M.F. \& CÉSAR, I.I. 2015. A new species of Hyalella (Crustacea, Amphipoda, Dogiolinotidae) from the Atlantic Forest, of Misiones, Argentina. Zookeys, 481: 25-38. http://doi: 10.3897/zookeys.481.9037

GONZÁLEZ, E.R., WATLING, L. 2003a. A new species of Hyalella from Brazil (Crustacea: Amphipoda: Hyalellidae), with redescriptions of three other species in the genus. Journal of Natural History, 37: 2045-2076. http://dx.doi.org/10.1080/00222930210133237

GONZÁLEZ, E.R \& WATLING, L. 2003b. A new species of Hyalella from Colombia, and the redescription of $H$. meinerti Stebbing, 1899 from Venezuela (Crustacea: Amphipoda). Journal of Natural History, 37: 2095-2111. http://dx.doi.org/10.1080/00222930210133255

GONZÁLEZ, E.R., BOND-BUCKUP, G. \& Araujo, P.B. 2006. Two new species of Hyalella from Southern Brazil (Amphipoda: Hyalellidae) with a taxonomic key. Journal of Crustacean Biology, 26: 355365. http://dx.doi.org/10.1651/c-2599.1

LOWRY, J.K \& MYERS, A.A. 2013. A phylogeny and classification of the Senticaudata subord. nov. (Crustacea: Amphipoda). Zootoxa, 3610(1): 1-80. http://dx.doi.org/10.11646/zootaxa.3610.1.1

MARRÓN-BECERRA, A., HERMOSO-SALAZAR, M. \& SOLÍS-WEISS, V. 2014. Hyalella cenotensis, a new species of Hyalellidae (Crustacea, Amphipoda) from the Yucatán Peninsula, Mexico. Zootaxa, 3811(2): 262-270. http://doi.org/10.11646/zootaxa.3811.2.7

MALTCHIK, L. \& ROLON, A.S. 2010. Does flooding of rice fields after cultivation contribute to wetland plant conservation in southern Brazil? Applied Vegetation Science 13: 26-35. doi: 10.1111/j.1654109X.2009.01046.x 
Streck-Marx, M. T. \& Castiglioni, D.S.

RODRIGUES, S.G., BUENO, A.A.P. \& FERREIRA, R.L. 2012. The first hypothelminorheic Crustacea (Amphipoda, Dogielinotidae, Hyalella) from South America. Zookeys, 236: 65-80. http://dx.doi.org/10.3897/ zookeys.236.3930

RODRIGUES, S.G., BUENO, A.A.P. \& FERREIRA, R.L. 2014. A new troglobiotic species of Hyalella (Crustacea, Amphipoda, Hyalellidae) with a taxonomic key for the Brazilian species. Zootaxa, 3815: 200-214. http://dx.doi.org/10.11646/zootaxa.3815.2.2

RODRIGUES, S.G. 2016. Filogenia molecular, biogeografia e estrutura populacional de anfípodos de água doce (Crustacea, Hyalellidae) da América do Sul. Tese de Doutorado, Programa de Pós-Graduação em Ecologia Aplicada, UFLA. 125 p.
RODRIGUES, S.G., SENNA, A.R., QUADRA, A. \& BUENO, A.A.P. 2017. A new species of Hyalella (Crustacea: Amphipoda: Hyalellidae) from Itatiais National Park, Brazil: an epigean freshwater amphipod with troglobiotic traits at 2,000 meters of altitude. Zootaxa, 4344(1): 147-159. http://doi.org/10.11646/zootaxa.4344.1.6

STRECK, M.T. CARDOSO, G.M., RODRIGUES, S.G., GRAICHEN, D.A.S \& CASTIGLIONI, D.S. 2017. Two new species of Hyalella (Crustacea, Amphipoda, Hyalellidae) from state of Rio Grande do Sul, Southern Brazil. Zootaxa, 4337 (2): 263-278. https://doi.org/10.11646/zootaxa.4337.2.5

ZIMMER, A., ARAUJO, P.B. \& BOND-BUCKUP, G. 2009. Diversity and arrangement of the cuticular structures of Hyalella (Crustacea: Amphipoda: Dogielinotidae) and their use in taxonomy. Zoologia, 26 (1): 127-142. http://dx.doi.org/10.1590/s1984-46702009000100019 